\title{
9. Indigenous Data Sovereignty: Implications for Data Journalism
}

\author{
Tahu Kukutai and Maggie Walter
}

\begin{abstract}
This chapter discusses some of the potential harms of digitalization and considers how Indigenous data sovereignty (ID-SOV), as an emerging site of science and activism, can mediate risks while providing pathways to benefit.
\end{abstract}

Keywords: Indigenous data sovereignty, activism, data journalism, statistical surveillance, Indigenous peoples

Digital technologies, including monitoring and information technologies and artificial intelligence (AI), are increasingly becoming a feature of Indigenous peoples' lives, especially for peoples in developed and transition economies. Yet, while data-driven technologies can drive innovation and improve human well-being, Indigenous peoples are unlikely to share equitably in these benefits given their nearly universal position of socio-economic, cultural and political marginalization. The growing use of linked and integrated big data by governments and businesses also brings significant risks for Indigenous peoples. These include the appropriation of cultural knowledge and intellectual property; the exploitation of land and other natural resources; and the perpetuation of discrimination, stigma and ongoing marginalization. These risks are amplified by journalistic storytelling practices that recycle well-rehearsed tropes about Indigenous dysfunction. In this chapter we discuss some of the potential harms of digitalization and consider how Indigenous data sovereignty (ID-SOV), as an emerging site of science and activism, can mediate risks while providing pathways to benefit. We conclude by suggesting that ID-SOV research and networks also represent valuable sources of data and data expertise that can inform more

Bounegru, L. and J. Gray (eds.), The Data Journalism Handbook: Towards a Critical Data Practice. Amsterdam: Amsterdam University Press, 2021 DOI 10.5117/9789462989511_CHO9 
equitable, critical and just approaches to journalism involving Indigenous peoples and issues.

\section{Indigenous Peoples and Data}

There are an estimated 370 million Indigenous peoples globally, covering every continent and speaking thousands of distinct languages (United Nations, 2009). The actual global count is impossible to know as the majority of countries that encapsulate Indigenous peoples do not identify them in their national data collections (Mullane-Ronaki, 2017). Notwithstanding these Indigenous "data deserts" and the significant global variation in Indigenous political autonomy and living standards, there is ample evidence that Indigenous people are often among the poorest population groups in their homelands, carrying the heaviest burden of disease, over-incarceration and broad spectrum inequality (Anderson et al., 2016; Stephens et al., 2006). This shared positioning of marginalization is not coincidental; it is directly related to their history as colonized and dispossessed peoples. However, the devastating consequences of colonialism and its bedfellows, White supremacy and racism, are rarely acknowledged, let alone critiqued, in mainstream journalistic portrayals of Indigenous peoples and communities.

Indigenous peoples have always been active in what is now known as data, with ancient traditions of recording and protecting information and knowledge through, for example, art, carving, totem poles, song, chants, dance and prayers. Deliberate efforts to expunge these practices and knowledge systems were part and parcel of colonizing processes. At the same time Indigenous peoples were made legible through the writings of European travellers, explorers and scientists who were presented as more objective, scientific and credible "knowers" of Indigenous peoples and their cultures. Over time the racial hierarchies that justified and sustained colonialism became naturalized and embedded through ideological structures, institutional arrangements (e.g., slavery, segregation) and state classifying practices. For example, Aboriginal and Torres Strait Islander people in Australia were specifically excluded from the national census until 1971 and this exclusion was linked to similar exclusions from basic citizenship rights such as the Age Pension (Chesterman \& Galligan, 1997). In modern times, the power to decide whether and how Indigenous peoples are counted, classified, analyzed and acted upon continues to lie with governments rather than Indigenous peoples themselves. Transforming the locus of power over Indigenous data from the nation state back to Indigenous peoples lies at the heart of ID-SOV. 


\section{Defining ID-SOV}

The terminology of ID-SOV is relatively recent, with the first major publication on the topic only surfacing in 2015 (Kukutai \& Taylor, 2016). ID-SOV is concerned with the rights of Indigenous peoples to own, control, access and possess data that derive from them, and which pertain to their members, knowledge systems, customs or territories (First Nations Information Governance Centre, 2016; Snipp, 2016). ${ }^{1}$ ID-SOV is supported by Indigenous peoples' inherent rights of self-determination and governance over their peoples, country (including lands, waters and sky) and resources as described in the United Nations Declaration on the Rights of Indigenous Peoples (UNDRIP). ${ }^{2}$ Implicit in ID-SOV is the desire for data to be used in ways that support and enhance the collective well-being and self-determination of Indigenous peoples - a sentiment emphasized by Indigenous NGOs, communities and tribes (First Nations Information Governance Centre, 2016; Hudson et al., 2016). In practice ID-SOV means that Indigenous peoples need to be the decision-makers around how data about them are used or deployed. ID-SOV thus begets questions such as: Who owns the data? Who has the power to make decisions about how data is accessed and under what circumstances? Who are the intended beneficiaries of the data and its application?

ID-SOV is also concerned with thorny questions about how to balance individuals' rights (including privacy rights), risks and benefits with those of the groups of which they are a part. The focus on collective rights and interests is an important one because it transcends the narrow focus on personal data protection and control that permeates policy and regulatory approaches such as the European Union's General Data Protection Regulation (GDPR). Anglo-European legal concepts of individual privacy and ownership translate poorly in Indigenous contexts where individuals are part of a broader group defined, for example, by shared genealogies or genes. In such contexts the sharing of data that encodes information about other group members cannot rest solely on personal consent but must also take account of collective rights and interests (Hudson et al., 2020). Closely linked to ID-SOV is the concept of Indigenous data governance, which can be broadly defined as the principles, structures, accountability mechanisms

1 In Aotearoa New Zealand, the ID-SOV network Te Mana Raraunga defines Māori data as "digital or digitisable information of knowledge that is about or from Maori people, our language, cultures, resources or environments" (Te Mana Raraunga, 2018a).

2 https://www.un.org/esa/socdev/unpfii/documents/DRIPS_en.pdf 
legal instruments and policies through which Indigenous peoples exercise control over Indigenous data (Te Mana Raraunga, 2018a). Indigenous data governance, at its essence, is a way of operationalizing ID-SOV (Carroll et al., 2017). It is through Indigenous data governance that Indigenous rights and interests in relation to data can be asserted (Walter, 2018).

\section{Statistical Surveillance and Indigenous Peoples}

The profiling of Indigenous populations and the targeting of services is not new; surveillance by the state, its institutions and agents have long been enduring characteristics of colonialism (Berda, 2013). Even through the official exclusion of Aboriginal and Torres Strait Islander peoples from the national census in Australia, surveillance of Aboriginal populations was a constant process (Briscoe, 2003). What is new in the social policy arena are the opaque, complex and increasingly automated processes that shape targeting and profiling (Henman, 2018). As "data subjects" (Van Alsenoy et al., 2009), Indigenous peoples are included in a diverse range of data aggregations, from self-identified political and social groupings (e.g., tribes, ethnic/racial groups), to clusters of interest defined by data analysts on the basis of characteristics, behaviour and/or circumstances.

The position of Indigenous peoples within these data processes is not benign. Rather, while the sources of data about Indigenous peoples are rapidly evolving, the characteristics of those data as a relentless descriptive count of the various dire socio-economic and health inequalities borne by Indigenous peoples remains the same. Walter (2016) has termed these data 5 D data: Data that focus on Difference, Disparity, Disadvantage, Dysfunction and Deprivation. Evidence to support this claim is easily found through a Google search of the term "Indigenous statistics" or by inserting the name of an Indigenous people into the search (i.e., Native American, Aboriginal and Torres Strait Islander, Maori, Native Hawaiian, First Nations, Alaskan Native). What comes up, invariably, is a sad list detailing Indigenous overrepresentation in negative health, education, poverty and incarceration rate data.

The impact of $5_{5} \mathrm{D}$ data on Indigenous lives is also not benign. As the primary way that Indigenous peoples are positioned in the national narrative, such data shape the way the dominant non-Indigenous population understand Indigenous peoples. These data stories that influence these narratives are frequently promulgated through media reporting. For example, Stoneham (2014) reports on a study of all articles relating to Aboriginal 
Health from four prominent Australian online and print media sources. Three quarters of these articles were negative, focusing on topics such as alcohol, child abuse, drugs, violence, suicide and crime, compared to just $15 \%$ of articles deemed positive ( $11 \%$ were rated as neutral); a ratio of seven negative articles to one positive. Such narratives are also mostly decontextualized from their social and cultural context and simplistically analyzed, with the Indigenous population systematically compared to the (unstated) non-Indigenous norm (Walter \& Andersen, 2013). The result is that in the national imagination Indigenous peoples are pejoratively portrayed as the problem rather than as peoples bearing an inordinate burden of historic and contemporary inequality.

There is growing evidence that the racial biases embedded in big data, and the algorithms developed to analyze them, will amplify, rather than reduce the impact of $5 \mathrm{D}$ data on Indigenous peoples (Henman, 2018). So, while in highly developed settler states such as Aotearoa NZ and Australia the prejudicial outcomes of discriminatory policies have been unwound, to some extent, by Indigenous activism and social justice movements over many years, these emerging data practices may unintentionally entrench existing inequalities and reactivate older patterns. With the detection (and amelioration) of social problems now increasingly deferred to algorithms, the likelihood of injustice reworking its way back into the system in ways that disadvantage Indigenous peoples rises exponentially. Reworking the old adage around data: If the algorithm data "rules" target problems where Indigenous peoples are over-represented; then the problematic Indigene will be the target.

\section{ID-SOV in Practice}

ID-SOV movements are active in the so-called CANZUS (Canada, Australia, New Zealand and the United States) states and have growing influence. The ID-SOV pioneers are First Nations in Canada. Tired of non-Indigenous data users assuming the mantle of unbiased "experts" on First Nations peoples, community activists developed a new model which provided for First Nations collective control over their own data. The trademarked OCAP ${ }^{\circledR}$ principles assert their right to retain collective ownership of , control over, access to and possession of First Nations data and, 20 years on, have become the de facto standard for how to conduct research with First Nations (First Nations Information Governance Centre, 2016). In Aotearoa NZ the Māori data sovereignty network Te Mana Raraunga (TMR) was established in 2015, drawing together more than a hundred Māori researchers, practitioners 
and entrepreneurs across the research, IT, community and NGO sectors. ${ }^{3}$ TMR has been very active in promoting the need for Māori data sovereignty and data governance across the public sector, and in 2018 took the national statistics agency to task over its handling of the New Zealand Census (Te Mana Raraunga, 2018b) which was widely reported by mainstream and Indigenous media. TMR has also raised concerns relating to "social licence" for data use in the context of Māori data (Te Mana Raraunga, 2017) and developed its own set of Māori data sovereignty principles to guide the ethical use of Māori data (Te Mana Raraunga, 2018a). For advocates of Māori data sovereignty, including TMR, the goal is not only to protect Māori individuals and communities from future harm and stigma, but also to safeguard Māori knowledge and intellectual property rights, and to ensure that public data investments create benefits and value in a fair and equitable manner that Māori can fully share in.

In Australia, the Maiam nayri Wingara Indigenous Data Sovereignty Collective was formed in 2016, and in 2018, in partnership with the Australian Institute of Indigenous Governance, issued a communique from a national meeting of Aboriginal and Torres Strait Islander leaders. The communique stated the demand for Indigenous decision and control of the data ecosystem, including creation, development, stewardship, analysis, dissemination and infrastructure (Maiam nayri Wingara Indigenous Data Sovereignty Collective \& Australian Indigenous Governance Institute, 2018). Maiam nayri Wingara, alongside other Indigenous bodies, is actively advocating for changes in the way Indigenous data in Australia is conceptualized, purposed, deployed, constructed, analyzed and interpreted. The aspiration is to activate the contribution data can make to Aboriginal and Torres Strait Islander wellbeing. What is required for this to happen is a reinvention of the relationship between Indigenous data holders/generators and the Indigenous peoples to whom those data relate to one built around Indigenous data governance.

\section{Towards a Greater Role for ID-SOV Initiatives in Data Journalism}

Data journalism is well positioned to challenge rather than reinscribe the five Ds of Indigenous data. Data journalists have ample opportunities to rethink how they use data to represent Indigenous peoples and stories, and to expose the complex ways in which Indigenous data is produced, controlled, disseminated and "put to work" by government and industry. In so doing data 
journalists ought not to rely on non-Indigenous data producers and users; the rise of ID-SOV networks means there are a growing number of Indigenous data experts to call on. Many of those involved in ID-SOV work have close ties to their communities and are driven by a strong commitment to data justice and to finding ways for "good data" to empower "good outcomes." The questions raised by ID-SOV, particularly around data ownership, control, harm and collective benefit, have wider application beyond Indigenous communities. By engaging with ID-SOV approaches and principles, data journalists can open up meaningful spaces for Indigenous perspectives and concerns to frame their narratives, while also sharpening their lenses to hold those in power to account.

\section{Works Cited}

Anderson, I., et al. (2016). Indigenous and tribal peoples' health (The Lancet-Lowitja Institute Global Collaboration): A population study. The Lancet, 388(10040), 131-157. https://doi.org/10.1016/So140-6736(16)00345-7

Berda, Y. (2013). Managing dangerous populations: Colonial legacies of security and surveillance. Sociological Forum, 28(3), 627-630. https://doi.org/10.1111/socf.12042

Briscoe, G. (2003). Counting, health and identity: A history of aboriginal health and demography in Western Australia and Queensland 19oo-1940. Aboriginal Studies Press.

Carroll, R. S., Rodriguez-Lonebear, D., \& Martinez, A. (2017). Policy brief(Version 2): Data governance for native nation rebuilding. Native Nations Institute. usindigenousdata.arizona.edu

Chesterman, J., \& Galligan, B. (1997). Citizens without rights: Aborigines and Australian citizenship. Cambridge University Press.

First Nations Information Governance Centre. (2016). Pathways to First Nations' data and information sovereignty. In T. Kukutai \& J. Taylor (Eds.), Indigenous data sovereignty: Toward an agenda (pp. 139-155). Australian National University Press. https://doi.org/10.22459/CAEPR38.11.2016.08

Henman, P. (2018). Of algorithms, apps and advice: Digital social policy and service delivery.Journal of Asian Public Policy, 12(2), 1-19. https://doi.org/10.1080/17516 234.2018.1495885

Hudson, M., et al. (2020). Rights, interests and expectations: Indigenous perspectives on unrestricted access to genomic data. Nature Reviews Genetics, 21(6), 377-384. https://doi.org/10.1038/s41576-020-0228-x

Hudson, M., Farrar, D., \& McLean, L. (2016). Tribal data sovereignty: Whakatōhea rights and interests. In T. Kukutai \& J. Taylor (Eds.), Indigenous data sovereignty: 
Toward an agenda (pp. 157-178). Australian National University Press. https:// doi.org/10.22459/CAEPR38.11.2016.o9

Kukutai, T., \& Taylor, J. (Eds.). (2016). Indigenous data sovereignty: Toward an agenda. Australian National University Press.

Maiam nayri Wingara Indigenous Data Sovereignty Collective \& Australian Indigenous Governance Institute. (2018). Indigenous data sovereignty summit communique. https://web.archive.org/web/20190305225218/http://www.aigi.com. $\mathrm{au} /$ wp-content/uploads/2018/o7/Communique-Indigenous-Data-SovereigntySummit.pdf

Mullane-Ronaki, M.-T. T. K. K. (2017). Indigenising the national census? A global study of the enumeration of indigenous peoples, 1985-2014 [Thesis]. University of Waikato.

Snipp, M. (2016). What does data sovereignty imply: What does it look like? In T. Kukutai \& J. Taylor (Eds.), Indigenous data sovereignty: Toward an agenda (pp. 39-56). Australian National University Press.

Stephens, C., Porter, J., Nettleton, C., \& Willis, R. (2006). Disappearing, displaced, and undervalued: A call to action for Indigenous health worldwide. The Lancet, 367(9527), 2019-2028. https://doi.org/10.1016/So140-6736(o6)68892-2

Stoneham, M. (2014, April 1). Bad news: Negative Indigenous health coverage reinforces stigma. The Conversation. http://theconversation.com/ bad-news-negative-indigenous-health-coverage-reinforces-stigma-24851

Te Mana Raraunga. (2017). Statement on social licence. https://www.temanararaunga.maori.nz/panui/

Te Mana Raraunga. (2018a). Principles of Māori data sovereignty. https://www. temanararaunga.maori.nz/new-page-2/

Te Mana Raraunga. (2018b). Te Mana Raraunga statement on 2018 New Zealand Census of Population and Dwellings: A call for action on Māori census data. https://www.temanararaunga.maori.nz/panui/

United Nations. (2009). State of the world's indigenous peoples. https://www.un.org/ esa/socdev/unpfii/documents/SOWIP/en/SOWIP_web.pdf

Van Alsenoy, B., Ballet, J., Kuczerawy, A., \& Dumortier, J. (2009). Social networks and web 2.0: Are users also bound by data protection regulations? Identity in the Information Society, 2(1), 65-79. https://doi.org/10.1007/s12394-009-0017-3

Walter, M. (2016). Data politics and Indigenous representation in Australian statistics. In T. Kukutai \& J. Taylor (Eds.), Indigenous data sovereignty: Toward an agenda (pp. 79-98). Australian National University Press.

Walter, M. (2018). The voice of indigenous data: Beyond the markers of disadvantage. Griffith Review, 6o, 256.

Walter, M., \& Andersen, C. (2013). Indigenous statistics: A quantitative research methodology. Left Coast Press. 


\section{About the Authors}

Tahu Kukutai (Ngāti Tiipa tribe) is Professor at the National Institute of Demographic and Economic Analysis, the University of Waikato, and a founding member of the Māori data sovereignty network Te Mana Raraunga.

Maggie Walter $(\mathrm{PhD})$ is a palawa (Tasmanian Aboriginal) sociologist and a founding member of the Maiam nayri Wingara Australian Data Sovereignty Data Collective. 